\title{
CHALLENGES AND OPPORTUNITIES OF THE MACEDONIAN PENSION SISTEM ACCORDING THE EU RECOMMENDATIONS (SOCIAL, LEGAL AND FINANCIAL ASPECTS)
}

\author{
Kristina Misheva, PhD, Assistant Professor \\ University „Goce Delcev” - Shtip, Faculty of Law \\ „Krste Misirkov“ No.10-A P.O. Box 201, Shtip 2000, Republic of North \\ Macedonia \\ kristina.miseva@ugd.edu.mk
}

\section{Marija Ampovska, PhD, Assistant Professor}

University „Goce Delcev” - Shtip, Faculty of Law

„Krste Misirkov“ No.10-A P.O. Box 201, Shtip 2000, Republic of North Macedonia

marija.ampovska@ugd.edu.mk

\section{Biljana Todorova, PhD, Assistant Professor}

University „Goce Delcev” - Shtip, Faculty of Law

„Krste Misirkov“ No.10-A P.O. Box 201, Shtip 2000, Republic of North Macedonia

biljana.todorova@ugd.edu.mk

\begin{abstract}
The reformed pension system in the Republic of North Macedonia has created an interest based on three poles: legal, financial and social. Therefore, the paper aims to provide not only overview of the North Macedonian pension legislative, the model of financing of the reformed pension system but also to take into account the social character of the pension system. Following the basic European values and the interception of the EC recommendations that were underline in the last 10 years for North Macedonia, the country remains moderately prepared in this area. The rapidly increased expenditure on pensions and the efforts to improve the legal, institutional and social framework on the North Macedonian pension system became new burden for the Public Pension Fund. Therefore, the sustainability and the efficiency of the contemporary pension system is under question mark.
\end{abstract}

This paper will explore the major challenges and opportunities that were foster by the new pension reforms from the reconstructed pension system. The one-pillared based system (Pay As You Go system - based on principle of generation solidarity,) has become system based on three 
pillars (fully funded mandatory pension insurance and fully funded voluntary pension insurance). Regarding the legal and financial aspects of the reformed pension system, there will be three areas of research emphasis: delayed transfer of funds from the state pension insurance fund to private funds, the procedures for supervising voluntary pension insurance schemes and the limits on investing in non-domestic securities. These three aspects resulted in a breach of the legislation on the management of deposits in Republic of North Macedonia, and they were not in line with the acquis under Financial Services Chapter that consists mostly of legal arrangements concerning with capital markets, insurance (including individual pension systems) and banking sectors. This is why they found their place in the annual reports (for 2015, 2016 and 2018) of the European Commission on the Republic of North Macedonia in negative connotation. Analysis of the legislation, as well as comparing the legislation with EU recommendation, is expected to answer the question if our country is complying with the recommendations.

The paper will be based on a legal, comparative, analytical and synthetic method that will provide a multidisciplinary approach in acquiring knowledge and in delivering results that will be of relevance to all involved stakeholders (future pensioners, pension funds, central and decentralized government).

Keywords: Reforms, pension system, EU recommendations, pensions, Public fund, fully funded mandatory, fully funded voluntary

\section{INTRODUCTION}

The European Commission in its Green Paper on pensions has pointed out the importance of pension systems being both adequate and sustainable. "A sustainable pension system is a system which is not a Ponzi-scheme i.e. which does not rely on perpetual increases in public debt. An adequate pension system is a system which allows for retirement pensions that provide reasonable income in relation to wages of working people." "The sustainability is jeopardized by inadequate pensions and increases, and unaffordable pension systems that are not reformed may ultimately collapse under the weight of ageing populations, and so prove inadequate. ${ }^{2}$ Following this major consultation, the Commission set out its definitive vision on Pensions in its 2012 White Paper an Agenda for Adequate, Safe and Sustainable Pensions. ${ }^{3}$

1 Šnje, V., Pension systems and pension reforms: Case of Croatia (with a review of reforms in 13 emerging European countries), October 2011, p.11, available at [http://arhivanalitika.hr/wp/wp-content/uploads/2017/02/PENSION-SYSTEMS-AND-PENSION-REFORM_final.pdf] Accessed 10.04.2019

2 European Commission - Green Paper towards adequate, sustainable and safe European pension systems SEC(210)830, Brussels [2010]

3 European Commission - White Paper An agenda for Adequate, Safe and Sustainable Pensions, Brussels [2012], available at [https://eur-lex.europa.eu/LexUriServ/LexUriServ.do?uri=COM:2012:0055:F IN:EN:PDF] Accessed 02.03.2019 
The two main themes to ensure pensions were adequate and sustainable were: better balancing the time spent in work and retirement and developing complementary private retirement savings. ${ }^{4}$

One of the main Europe's structural weaknesses concerning the pension system is the fact that the demographic ageing is accelerating. "As the baby-boom generation retires, the EU's active population will start to shrink as from 2013/2014. The number of people aged over 60 is now increasing twice as fast as it did before 2007 - by about two million every year compared to one million previously. The combination of a smaller working population and a higher share of retired people will place additional strains on our welfare systems." ${ }^{\text {" }}$

Facing the problems about the sustainability of the pension systems was not challenge only in the EU member-states, but in North Macedonia, also. The multipillar pension system reform was suggested by the World Bank, and three-pillar model that was conducted in the most of the Middle- East countries (Latvia, Lithuania, Estonia, Poland, Slovakia, Hungary, Romania and Bulgaria). ${ }^{6}$ The aim for the governments was to build long -term pension strategy where the public pension funds will bear the unexpected economical situations in future on one hand, but also to provide adequate income in retirement for the pension insurances, on the other hand. Although, there are significant differences in the national pension systems in the EU member states, still they are following similar polices common to the rights of retirement, social security and the model of financing the pension systems. So most of the European countries have implemented the following three-pillar pension system:

- The Public pension system based on pay as you go system (First pillar). It`s a - solidarity system based on contributions. The Public pension and disability Fund is financed from the contributions of the gross income of the employee. The pension depends of the employee's years of service and income/ salary at the end of the working career and the Government, usually, defines the pensions.

- Mandatory Fully Funded Pension Insurance (The Second pillar). The system of defined benefits/defined contributions (individual approach and approach based on pension schemes) and has many different modalities. But, the base

Eatock, D., European Union pension systems Adequate and Sustainable?, Briefing November 2015, European Parliamentary Research System, available at [http://www.europarl.europa.eu/RegData/ etudes/BRIE/2015/571327/EPRS_BRI(2015)571327_EN.pdf] Accessed 02.03.2019

5 European Commission: Europe 2020, A European strategy for smart, sustainable and inclusive growth, Brussels, 3.3.2010 Available at [http://ec.europa.eu/eu2020/pdf/COMPLET\%20EN\%20BARROSO\%20\%20\%20007\%20-\%20Europe\%202020\%20-\%20EN\%20version.pdf] Accessed 12.04.2019

6 Talevski, P., The Financing of the pension systems, Selektor, Skopje, 2009, pp. 49 
is that the contributions are defined, but the pensions will be defined after accumulation of the asset of the private fund which is consisted of units. The members of the mandatory pension fund have individual private account and the pension benefit will depend on the capitalization value of the fund.

- Voluntary Fully Funded Pension Insurance (the third pillar). This pension insurance system may cover pension beneficiaries that are not covered with the mandatory pension insurance and pension beneficiaries covered with the mandatory pension insurance for purposes of gaining additional income after retirement. This pension system works in similar way as the second pillar, by capitalization of the fund assets. The amount of the pension benefit is not defined before hand and it depends on the paid contributions and the investment policy of the pension management companies.

In the traditional pension system, all eligible employees are automatically enrolled in the pension plan defined by the state. In most of the counties, it is compulsory to pay monthly pension contributions, so the so-called "state pension" could be provide to the retired. ${ }^{7}$

The second pillar (the mandatory private fully funded system) is financed by the percentage of the pension contribution from the members of the public pension fund and the capitalization of the asset.

The model of three-pillar pension system was adopted also in the most of ExYugoslavian countries, for example Slovenia, Croatia and Serbia. Three countries (Croatia, Macedonia, Kosovo) introduced the second pillar based on managed mandatory individual retirement accounts. Only Croatia and Macedonia have fully developed systems comprising all three pillars: the defined benefit PAYG system, second-pillar managed individual retirement accounts and third-pillar voluntary pension funds. ${ }^{8}$

\section{SOCIAL ASPECTS OF THE PENSION SYSTEM REFORMS IN REPUBLIC OF NORTH MACEDONIA}

A pension aims to protect retired people from poverty and allow them to enjoy decent living standard. They are the main source of income for a significant number of populations in every country. According to the public opinion in $\mathrm{EU}^{9}$ the

[https://dictionary.cambridge.org/dictionary/english/state-pension] Accessed 09.02.2019

Šonje, op. cit. note 1 , p. 11

Public opinion survey on The future of pension systems that was carried out at the request of the Directorate-General Employment and Social Affairs and organised by the Public Opinion Analysis Sector of the Directorate-General Press and Communication in all the Member at States of the European 
primary goal of a good pension scheme should be to protect elderly people against the risk of poverty, which stresses the 'social protection' function a good pension scheme should fulfil. It is also believed that a good pension system should allow everybody to maintain an adequate standard of living relative to their income before retirement, as well as that a good pension system should contribute to greater equality in income and living conditions amongst the elderly.

Most of the retired people during the working period contributed a part of their gross salary into funds of that time. They contributed with their own assets (generations insurance and a principle of solidarity) the purpose of which was future pensions. This means that their pension is a social category and that the state may not limit, stop or eliminate the right to social security.

In the Republic of North Macedonia (following in the text: Macedonia), based on the fact that the complete economic and social system narrows the possibilities for the complete exercising of the right to pension as an economic category, more and more the pension gets a social character, causing changes / interventions as a financial category. ${ }^{10}$

According the scholars a social pension (or non-contributory pension) is a stream of payments from state to an individual that starts when someone retires and continues in payment until he/she dies. The social pension is different from other types of pension since its eligibility criteria do not require former contributions of an individual, but his citizenship or residency and age or other criteria set by government. ${ }^{11}$

The main feature that distinguishes social pensions from other types of pensions is that the eligibility criteria do not include a history of earmarked contributions having been made by the individual in question or his employer. They are pure cash transfers rather than savings or insurance schemes. ${ }^{12}$

On the basis of the assessment that there are people in our country who don't fulfill the conditions for any type of pension, the Ministry of Labor and Social Policy

Union between September 17 and October 26, 2001, p. 44-50, available at [http://ec.europa.eu/ commfrontoffice/publicopinion/archives/ebs/ebs_161_pensions.pdf] Accessed 14.04.2019

10 The right to income security in old age, as grounded in human rights instruments and international labour standards, includes the right to an adequate social security pension. In many countries with high shares of informal employment, pensions are accessible only to a minority, and many older persons can rely only on family support. Source: SOCIAL PROTECTION POLICY PAPERS, Social protection for older persons: Key policy trends and statistics, [https:/www.ilo.org/wcmsp5/groups/ public/---dgreports/---dcomm/documents/publication/wcms_310211.pdf] Accesed 01.03.2019

11 Blake, D., Pension Economics. Hoboken, NJ: John Wiley, 2006, p. 19

12 Rajan, S.I., Social pensions for the poor elderly: how effective?, Economic and Political Weekly, 2001 
proposed an introduction of this type of pension - the social pension, as a novelty in the Macedonian pension system. This type of pension was introduced in our pension system in the Proposal of the Law on Social security of old age people. ${ }^{13}$ That is one more element in the strengthening the social character of the pensions in our country. ${ }^{14}$ According to this Proposal, the state is determined to pay to people being 65 years old and above, about $6.000,00 \mathrm{MKD}$ monthly, which is approximately equivalent to 100 EUR.

As mentioned before, there are significant country differences in the pension incomes. This is the reason why EU protects the pension rights of people who move between EU counties, insures protection of state pensions, and enables cross-border pensions.

The country's intention is to make consolidated pension system and to ensure a sustainable and adequate pension system, in long term. This is in line with the tendencies in EU strategic documents on pensions, according which "an adequate and sustainable retirement income for EU citizens now and in the future is a priority for the European Union. Achieving these objectives in an ageing Europe is a major challenge." 15 The authorities in Macedonia have based this process on the following: to adjust the rate of contributions, to harmonize the pensions, to adjust the replacement rate (one pillar/ two pillars) and to correct the miscalculations in distribution of the second pillar. ${ }^{16}$

The literature identifies several key factors that have an impact on the pension system, those are: demographic changes, movement in the labor market and the harmonization of the pensions with the economic potential. ${ }^{17}$

13 Proposal: The Government of the Republic of North Macedonia, Skopje, March 2019

14 There are a noncontributory or "zero pillar" (in the form of a demogrant or social pension) that provides a minimal level of protection. Zero pillars address the risk of lifetime poverty and liquidity constraints. These may preclude, or be strongly associated with, minimal participation in the formal or wage economy and the related capacity to accumulate meaningful individual savings. See more in: Holzmann, R.; Hinz, R, Old-age income support in the 21st century: an international perspective on pension systems and reform. The International Bank for Reconstruction and Development, Washington, D.C., 2001, p.42

15 European Commission - Green Paper towards adequate, sustainable and safe European pension systems SEC(210)830, Brussels [2010], p.2

16 [http://mtsp.gov.mk/content/pdf/dokumenti/2018/MTSP\%20prezentacija\%2002.pdf] Accessed 03.02 .2019

17 Verbič, M.; Majcen, B.; Nieuwkoop, R, V., Sustainability of the Slovenian Pension System: An Analysis with an Overlapping-Generations General Equilibrium Model, Institute for Economic Research, Ljubljana, Slovenia. 2014, p. 62 
Following are the objective reasons for the necessity for changes and interventions in the Macedonian pension system:

Firstly, the dynamics of changes in the labor market, economic flows and demographic trends. There are high rates of unemployment in Macedonia according to the degree and type of education as well as according to the percentage (which is now about $20 \%$ of the population fit for work). In such conditions, the employers, particularly in the private sector, have opportunities and avoid the regular signing of employment agreements (so that they don't contribute in the pension fund), or they use other ways to evade the obligations towards the state. At the same time, the average life span of the population in the country is prolonged and the number of pension beneficiaries is on the rise (individually the period of use of pensions is on the increase, too). ${ }^{18}$

Second, a deficit in the Macedonian Pension and Disability Insurance Fund due to the reduced rates of contribution and harmonization of pensions according to parameters which were not adequate to the economic growth of the country.

The pressure for higher pension is moved, mainly, by the power of pensioners to make an impact on the politics, due to the fact that their number is on the rise and they form a significant electoral body. ${ }^{19}$ Therefore, in the period from 2007 to 2016, on several occasions, all the pensions were increased linearly, most often in the periods of elections - campaigns and provision of voters. This action confirmed statistically and analytically, has no ground in the legal provisions and it doesn't arise from the economic results.

Practice shows situations when a part of the salaries of employees are regularly registered (through appropriation of respective contributions in the pension fund), and a part is given to employees as an author's fee which are subject to much lower tax rate and there are no pension contributions. So, employees, in reality, have higher income in relation to the salary which is a basis of the pension contribution.

Third, the problem of inequality of pensions of the present and future pensioners. Fourth, the problem of unequal distribution in the two pillar pension system.

18 So, former average life span of about 75 years currently is between 77 and 78 years. Between 2005 and 2015 average expected life span in Macedonia increased 1,6 years. Compared with the data on the developed countries and countries from the region, Macedonia has the highest expected average life span (except Bulgaria) Nikolov, M.; Shukarov, M; Velkovska, I., Sustainability of the Republic of Macedonia pension fund, Economic analysis centre, Skopje, 2017, p. 8

19 Kruse, A., A Stable Pension System: The Eighth Wonder, in: Bengtsson, T. (ed.), Population Ageing - A Threat to the Welfare State? Research in Labor Economics 22, 2010, p. 369 - 413. 
Population ageing, the fall of birthrate, the increase of the expected life span are part of the factors causing a pressure on the traditionally organized pension systems to be sustainable, fair and efficient. ${ }^{20}$

According the official statistical e- reports published by the Macedonian Pension Insurance and Disability Fund in 2015 the total number of the pensioners was 301.728 , of which 299.640 were pension beneficiaries based on employment, the total average paid pension was 13.095 denars, but the average old-pension was 14.449 denars. ${ }^{21}$ In 2016 the total number of the pensioners was 307.610, of which 305.766 are pension beneficiaries based on employment, the total average paid pension was 13.754 denars, but the average old-pension was 15.062 denars. $^{22}$ In December 2017 the total number of pensioners in Macedonia was 312.398, pension beneficiaries based on employment were 310.744 , the total average paid pension was 13.954 denars. But, the average old-pension was 15.229 denars. ${ }^{23}$ In December 2018 the total number of pensioners in Macedonia was 317.278, of which pension beneficiaries based on employment are 315.780 , the total average paid pension was 14.445 denars. But, the average old- pension was 15.717 denars. ${ }^{24}$

This shows that there are tends of increasing the paid amount of the average pension and the number of pensioners (population ageing), therefore the fiscal burden caused form the Public Fund may lead to serious consequences to the entire pension system and in long term negative We consider that these indicators are in the framework of the general development of the country and possibilities for maintenance of the pension system.

A part of the pension treatment as a social category is the intention of the society to provide a systematic approach in the pension increase which will be based on economy real growth. It means to increase the pension amount two times per annum through an analytical review of the increase of the living expenses and provision of a real purchasing power by such frame of pensions. If a real growth

20 Verbič; Majcen; Nieuwkoop, op. cit. note 17

21 Statistical report, Pension and disability fund for December 2015. [http://www.piom.com.mk/statistika/statistika-2015/] Accessed 19.02.2019

22 Statistical report, Pension and disability fund for December 2016. [http://www.piom.com.mk/statistika/statistika-2016/] Accessed 19.02.2019

23 Statistical report, Pension and disability fund for December 2017. [http://www.piom.com.mk/statistika/statistika-2017/] Accessed 19.02.2019

24 Statistical report, Pension and disability fund for December 2018. [http://www.piom.com.mk/statistika/statistika-2018/] Accessed 19.02.2019 
of the gross domestic production higher than 4 percent is realized there will be an additional increase of the pension amount. ${ }^{25}$

A special topic is the increasing deficit of the Macedonian Pension and Disability Insurance Fund, due which, (and due to the regular payment of pensions) transfers from the central budget into the pension fund were necessary which is an evidence of the social character of pensions in Macedonia. ${ }^{26}$

Planned reforms project a stabilization of the amount to be appropriated from the central budget to provide the amount of funds necessary for payment of pensions in Macedonia.

As a long-term venture it is planned to provide a gradual adjustment of the contribution rate which is appropriated from the salary for the pension and disability insurance. So, the rate of 18 percent in 2018 (of which 12 percent for the Macedonian pension and disability insurance fund and 6 percent for the second pension pillar), in 2019 this rate is projected to be 18,4 percent (of which 12,4 percent for the Macedonian pension and disability insurance fund and 6 percent for the second pension pillar), and in 2020 general rate of 18,8 percent of which 12,8 percent for the Macedonian pension and disability insurance fund and 6 percent for the second pension pillar. ${ }^{27}$

What about the amounts to be transferred from the central budget of the state regarding the provision of pensions payment?

Without a realized reform the amount of transfer in 2019 would be MKD 29,5 billion, in 2020 - MKD 31 billion and in 2021 - that amount would be MKD 32 billion.

By the implementation of the reforms the amount of transfer from the central budget into the pension fund would be in 2019 - MKD 28 billion (that is MKD 1,5 billion less), in 2020 - would be in the amount of MKD 28,5 billion (that is

25 In the application of this principle - harmonization of pensions based on overall / dominant movement of the living expenses: Portugal, Spain, France, Italy, Great Britain, Latvia, Poland, Hungary, Serbia, Montenegro, Turkey.

26 So, total transfer of funds from the central budget was MKD 12 billion in 2007, over MKD 15 billion in 2010 to MKD 25 billion in 2015, that is MKD 29 billion in 2018. [https://www.finance.gov.mk/ $\mathrm{mk} /$ node/7703] Accessed 03.02.2019

27 The average gross salary is in the amount of MKD 35.573,00 at the rate of 18 percentage contribution to the pension and disability insurance, MKD 6.403,00 would be appropriated while at the rate of 18,4 percent for this purpose MKD 6.545,00 would be appropriated or the difference would be MKD 142. Ministry of labor and social policy of the Republic of Macedonia, How to get a fair and stable pension system. [http://mtsp.gov.mk/content/pdf/dokumenti/2018/MTSP\%20prezentacija\%20 02.pdf] Accessed 03.02.2019 
MKD 2,5 billion less), and in 2021 the transfer would be MKD 29 billion (that is $\mathrm{MKD} 3$ billion less than if reforms are not implemented). ${ }^{28}$

\section{LEGAL AND FINANCIAL ASPECTS OF PENSION SYSTEM REFORM IN REPUBLIC OF NORTH MACEDONIA}

Before the pension system reform in Macedonia, the first pillar was financed from the pension contributions of the employee's, the central Budget and several years ago by dividends from the shares of the public share companies and the dividends from units form the limited liabilities companies (The Public Insurance and Disability Fund in the 90-tees became an owner of shares and units in many attractive companies in the country). ${ }^{29}$ This shares and units from the trade companies were regular income to the Public Pension and Disability Fund. ${ }^{30}$

Before 2000, the Public Pension and Disability Fund that provides pensions for the retired insurances and other citizens that are set under the provisions of the Law on Pension and Disability Insurance, define the pension contributions that are paid by the employers. By the Law, every month 18 percentage ${ }^{31}$ of the monthly income of the employee goes to this Fund. After 2002, 35\% from these 18 percentages are transferred to the personal accounts in the mandatory fully funded Funds. So this becomes a "person`s pension pot". ${ }^{32}$

After $2000,{ }^{33}$ the state started tremendous reconstruction in the national pension system. A new pension legal and institutional architecture stared to be build. The one pillar pension system was extended to three-pillar system. Macedonia has implemented the pension reforms as the most of the Middle East countries in Europe did, following the recommendations of the model that the World Bank suggested. The reform was in line with the pension system tendencies in EU at that time, having in mind that "...most EU Member States have carried out gradual and in some cases substantial pension reforms over the last decades in order to enhance

28 Ministry of Finance of the Republic of Macedonia, Draft Budget of the Republic of Macedonia for 2019. [https://www.finance.gov.mk/files/u3/Prelog\%20budzet\%202019\%2004.pdf] Accessed 03.02.2019

29 Law on transforming enterprises with Social Capital, Official Gazette no. 38/1993. By article 19 of this Law, the enterprises that were transformed $15 \%$ of their asset value were given as units or shares to the Public Pension and disability fund. Also, there companies were obligate on $2 \%$ fix dividends per year

$30 \quad$ Ibid. Article 19, paragraph, 3

31 This percentage vary by the life standard and the average salary.

32 [http://mapas.mk/mapas-en/index.php/pension-reform/membership-in-the-mandatory-private-pension-funds] Accessed 03.02.2019

33 In 2000, amended Law on pension and disability Insurance from 1993, Official Gazette 24/2000. In 2002 the Law on mandatory fully funded pension insurance was adopted, Official Gazette of the Republic of Macedonia No.29/2002 
fiscal sustainability, while maintaining adequate pension income. The intensity of pension reforms has been particularly strong since 2000 . These reforms have been implemented through a wide-range of measures that have modified substantially the pension system rules and parameters (e. g. pension age, retirement incentives, pension calculation, indexation, social contributions). Pension reforms have generally been implemented only gradually and over long time periods." ${ }^{34}$ It is also notable for the reforms of the pension systems in EU that although they differ markedly, they also adopted a number of key trends in order to protect adequacy and to respond better to changes in labor markets and gender roles. These trends were: encouraging more people to work more and longer so as to obtain similar entitlements as before: increases in pensionable ages; rewarding later and penalising earlier retirement, etc.; Measures to address adequacy gaps, e.g. through efforts to broaden coverage, support building up rights, ease access to pensions for vulnerable groups and increase in financial support for poorer pensioners; Gender dimension: women tend to predominate among those with atypical contracts, they tend to earn less than men and tend to take career breaks for caring responsibilities more often than men. ${ }^{35}$ Also, one of the commonly adopted trends was the move from largely single to multi-pillar systems. This is a result of the trend in most, but not all, Member States to lower the share of public PAYG pensions in total provision while giving an enhanced role to supplementary, prefunded private schemes, which are often of a Defined Contribution (DC) nature. ${ }^{36}$

The trend of moving to multi-pillar system was part of the reform in the pension system of Macedonia. There was a reform of the system's design that introduced the principle of fully-funded pension insurance, where in addition to the first pillar, two more pillars were added, a mandatory and a voluntary private pension pillar in 2008. ${ }^{37}$ The Fully funded pension insurance differs radically from the previous pension insurance because with this insurance each member has an individual account, which recorded its assets and provides a correlation and interdependence between the paid contributions and future pensions of the members. This insur-

34 Carone G.; Eckefeldt P.; Giamboni L., Laine V.; Pamies S., Pension reforms in the EU since the early 2000's: achievements and challenges ahead, European Commission, Directorate Generale for Economic and Financial Affairs-DG ECFIN 20 December 2016, p. 5, Available at [https://mpra.ub.unimuenchen.de/78163/] MPRA Paper No. 78163, posted 8 April 2017, Accessed 14.04.2019

35 European Commission - Green Paper towards adequate, sustainable and safe European pension systems SEC(210)830, Brussels [2010], p. 5

$36 \quad$ Ibid, p. 5

37 Law on Mandatory Fully Funded Pension Insurance, Official Gazette No. 29/2002, 85/2003, 40/2004, 113/2005, 29/2007, 88/2008, 48/2009, 50/2010, 171/2010, 36/2011, 98/2012, 13/2013, 164/2013, 44/2014, 192/2015, 30/2016 and 21/2018; Law on Voluntary Fully Funded Pension Insurance, Official Gazette No. 7/2008, 124/2010, 17/2011, 13/2013 
ance is based on accumulation of assets from contributions to individual accounts that are being invested and the return on investments with reducing the net costs of operating of the system, accumulated in individual accounts. ${ }^{38}$ The mandatory pension funds are pooled from all contributions of the pension fund members. Because of the safety and sustainable pension pillar, the company for managing mandatory pension funds invests the fund asset in no-risk securities (bonds or/ and other securities issued or guaranteed by the government of Macedonia on the domestic market) or in low risk securities ( deposits, units in investment funds, etc.). For example, in 2015, $60 \%$ of the investment portfolio of the both mandatory investment funds were in state securities issued by the Ministry of Finance or Central Bank and 22\% were invest in units of investment funds. ${ }^{39}$

Present, the pension beneficiary will earn pension consisted of two parts: the contribution from the gross salary of the pension member and the benefit earned by capitalization (accumulation) of the asset / units. The unit value depends of the investment policy that the management company of the private fund is conducting overall years. According the Laws the investment policy of these types investment funds must be with very low or no risk investment.

This was a period when vast new law and by- laws were brought in this area. Also, this is a period when the Agency for supervision of fully funded pension insurance - MAPAS was established, and the first two management companies for conducting mandatory Pension funds were established, and later the management companies for voluntary pension funds. New financial institutions comprise at the Macedonian financial market. These management companies for the mandatory pension funds were established by the two most powerful banks in that period: Komercijala Banka AD - Skopje and Tutunska Banka AD- Skopje as domestic capital and holdings from Slovenia. From 2005 their work was focus to attract and pull in more members as possible. A massive propaganda has started by these two banks and the Pension Companies managing Pension Funds. ${ }^{40}$

Starting from 2011, "the country's pension scheme, which is based on defined contributions, differs from the model applied in most of the EU countries; hence the respective EU acquis for supervision of the institutions for occupational re-

38 Mustafai, H., Pension System Reform in the Republic of Macedonia, International Refereed Scientific Journal Vision, Volume, Issue 1, March 2017, pp. 69-78

39 See Report for the conditions of the fully financing pension insurance, MAPAS, 2016, Skopje. [http:// mapas.mk/wp-content/uploads/2016/06/Izvestaj-KFPO-2015-MK.pdf] Accessed 01.03.2019

40 The both Pension Companies managing Pension Funds were established in Juni 2005. For more details see: [http://mapas.mk/wp-content/uploads/2018/07/zadolzitelno_reg.pdf]. In Feb 2019 the Agency for Supervision of Fully Funded Pension Insurance has issued license for one more pension management company. Now, there are three pension management companies 
tirement provisions cannot be applied. Pension funds can now invest a small part of their portfolio in equity capital and in municipal bonds, in order to stimulate SMEs and local development. The limitation on investing in non-domestic securities continues, which is contrary to the principles of EU law. However, the limit was relaxed to $50 \%{ }^{41}$ (30\% in 2010)." "42 This is why in 2012 new reforms were introduced to the Macedonian law. In 2012 the Macedonian Parliament adopted a new Law on Pension and Disability Insurance ${ }^{43}$, which follows on the previously planned reforms on the established three pillar pension system. As rights on pension and disability insurance once again are determined the following: the right to retirement, disability pension, the right to vocational rehabilitation and appropriate allowances, the right to family pension, right to compensation for physical damage, and right on minimal pension. ${ }^{44}$ Regarding the right of retirement there are no changes in the terms and conditions for its acquisition. The old-age pension is acquired by age of 64 years (men) or 62 years (women) with minimum 15 years of service. The Law only reduces the age limit of the insured who work in jobs placements where service is calculated with increased length. This Law didn't adopt the most common measure that EU countries have adopted in order to address pension sustainability challenges in the EU. That measure is consisted of raising pension ages. Nearly all European countries have increased the level of early and statutory retirement ages (the only exception being Luxembourg). In some cases (e.g. Greece, Sweden, France and Finland), particularly large increases have been legislated between 2008 and 2013. Looking forward, according to the Ageing Report 2015, only Luxembourg and Sweden have not legislated (further) rises of pension ages. Austria and Slovenia also project increases limited to women (in order to harmonise pension age between genders). ${ }^{45}$ On the other hand, the Law on Labor Relations ${ }^{46}$ with an amendment in 2014 has provided the possibility for the employee, with a statement addressed to the employer, to request for continuation of the employment contract for a maximum of 67 years for a man and 65 years for a woman, unless otherwise stipulated by law. ${ }^{47}$ In 2016 the Con-

41 Article 48 from the Law on Amending and Supplementing the Law on Mandatory Fully Funded Pension Insurance, Official Gazette No. 50/2010

42 European Commission - Commission Staff working paper: The FYROM 2011 Progress Report, Brussels, 2011

43 Official Gazette No. 98/2012

44 Article 5 of the Law on Pension and Disability Insurance, Official Gazette No. 98/2012

45 Carone, et al., op. cit. note 34, p. 8.

46 Law on Labor Relations, Official Gazette of the Republic of Macedonia No.62/2005; 106/2008; $161 / 2008$; 114/2009; 130/2009; 149/2009; 50/2010; 52/2010; 124/2010; 47/2011; 11/2012; $39 / 2012 ; 13 / 2013 ; 25 / 2013 ; 170 / 2013 ; 187 / 2013,113 / 2014,20 / 2015,33 / 2015,72 / 2015$, $129 / 2015,27 / 2016$ and $120 / 2018$ )

47 Official Gazzette 113/2014 
stitutional Court of Republic of Macedonia repealed this provision ${ }^{48}$ regarding the difference in age provided for man and women on the bases that this provision is not in accordance with the constitutionally established principle of equality of citizens on the basis of the sex defined in Article 9 of the Constitution. According to the positive law of Macedonia, both man and women can request continuation of the employment contract for a maximum of 67 years, which is in line with the EU measures mentioned above.

Regarding the pillar structure of the system, the first and second pillars remain compulsory and are based on two components: solidarity characteristic for the first pillar and funded component associated with the second pillar. ${ }^{49}$ In this period a big mistakes were made, by trying to attach and pull in more members by pulling out members from the Public Pension Fund without clearance how the pension will be withdrawal by the retired time. That is why the state forbidden the transfer for elder people and workers near to be retired. This was regulated later in 2012, by adopting the Law on Payment of Pensions and Pension Benefits from Fully Funded Pension Insurance, that also regulates the payments and the types of pensions and pension benefits from the second and the third pillar, was passed at the beginning of $2012 . .^{50}$

However, according to the report of the European Commission from 2012, after all the reforms in this period, in the area occupational pensions, the country was not yet sufficiently aligned with the acquis. ${ }^{51}$

With 2013 ending, Macedonian law has completed the eighth year of the implementation of the mandatory fully funded pension insurance in Macedonia. As of 31.12.2013, the mandatory fully funded pension insurance counted around 350,000 members. The assets in the mandatory pension funds for the first eight years have reached 27 billion denars (around 440 million Euros). The payments of the contributions into the mandatory pension funds started with the payment of the January 2006 wages, when the investment of these assets started to take place. The third pillar which became operational in 2009 , with two voluntary pension

48 Decision 114/2014-0-1 from 29.06.2016

49 Bornarova, S.; Bogoevska, N.; Trojevik, S., Pension System Reforms in the Republic of Macedonia: Expected Benefits and Challenges, in: Academic Journal of Interdisciplinary Studies MCSER Publishing - Rome, Italy, Vol. 2 No. 9, 2013, pp.393-399, pp. 396

50 Law on Payment of Pensions and Pension Benefits from Fully Funded Pension Insurance, Official Gazette No. 11/2012, 147/2015 and 30/2016

51 European Commission - Commission Staff working paper: The FYROM 2012 Progress Report, Brussels, 2012, available at [https://ec.europa.eu/neighbourhood-enlargement/sites/near/files/pdf/ key_documents/2012/package/mk_rapport_2012_en.pdf] Accessed 04.03.2019 
funds had around 18,500 members in 2013. At the end of 2013, the assets in the voluntary pension funds were around 318 million denars (or 5 million euro). ${ }^{52}$

Furthermore, the amendments to the Laws on mandatory and voluntary fully funded pension insurance in January 2013, gave grounds for the introduction of the risk-based supervision. These amendments also harmonized both Laws with the Law on payment of pensions and pension benefits from the fully funded pension insurance. In 2013, most of the secondary regulation was amended and harmonized with the Laws on mandatory and voluntary fully funded pension insurance and mostly with the Law on payment of pensions and pension benefits ${ }^{53}$.

Today, the Law on mandatory fully funded pension insurance provides limits on investing in non-domestic securities. Article 107 of this Law provides that no more than $50 \%$ of the value of the assets of the Pension Fund may be invested in assets issued by a foreign issuer outside Macedonia. With this restriction, no more than $30 \%$ of the Pension Fund asset value may be invested in:

- debt securities with an investment grade level rating by reputable international rating agencies issued by non-state foreign companies or banks of the European Union member-countries, OECD countries,

- shares issued by foreign companies or banks with a investment grade level rating by reputable international rating agencies, traded on the main stock exchange of the European Union member - countries, OECD countries and

- participation units, shares and other securities issued by authorized open-end and close-end investment funds established in the European Union membercountries, OECD countries that are invested primarily in equities quoted on stock exchange markets in their own countries. ${ }^{54}$

The pension reform caused additional budget expenditure for the Government, but also was additional financial challenge for Public Fund. In this period the Public pension fund has already lack and difficulties to cover the fund deficit, but moreover the reformed pension system demanded a certain percentage of the pension contributions to be transferred on the member's individual account in the mandatory private fund. This data shows that, as in most of the EU Member

MAPAS Report On the Developments in the Fully Funded Pension Insurance in 2013, Skopje, 2014 Ibid.

54 Article 107 (1)(a) related to Article105 paragraph (1) (i), (j) and (k) of the Law on Mandatory Fully Funded Pension Insurance 
States, ${ }^{55}$ in Macedonia benefits from funded schemes still play marginal role. According the Law on Mandatory Fully Funded Pension Insurance, Article 3 Paragraph 1, point 5: "Member of a mandatory pension fund" means an individual who has entered into a contract to be a member of a mandatory pension fund, or in whose name an account has been opened in a mandatory pension fund in cases specified in the Law, and his/her membership lasts until helshe acquires the right to a retiremen. That is why the withdrawals (transfers) from the Public to the Private funds was made partially and successively. Unfortunately, there process seems is not completed until nowadays. In 2018 the Ministry of Labor and Social Policy announced that 12.000 insurances are damaged by not being informed to make transfer to one of the Mandatory Pension Fund. ${ }^{56}$ According to the progress reports on Macedonia that are prepared by the European Commission, another problem with the transfers was the delay in transferring funds but this problem has been overcome and: "There are no longer delays in transferring funds from the state pension insurance fund to private funds, which had previously led to a breach of the legislation on management of deposits." 57

\section{CONCLUSION}

Despite the different level of socio-economy development of the countries in EU and in the region, they have faced with similar significant problems comprised from the pension reforms.

The Macedonian pension system was based on the principle of generation solidarity, i.e. pay-as-you-go (PAYG), where the current contribution payments are used to finance the current pensions. This system of solidarity became inadequate and burred with lack of funding. Pension reform was conducted and as a result, today, the pension system structure in North Macedonia consists of three pillars, where: the first pillar (mandatory) is still based on the principle of inter-generational solidarity, while the second (mandatory1) and third pillars (voluntary) operate on a fully-funded basis. ${ }^{58}$ The financial objective is the pension beneficiary to earn

55 European Commission - Green Paper towards adequate, sustainable and safe European pension systems SEC(210)830, Brussels [2010], p. 6. Just a few Member States with very acute public budget problems or well anchored automatic adjustment mechanisms were completed to reduce public pensions in payment

56 [https://meta.mk/mapas-ke-gi-vraka-parite-na-penzionerite-koi-se-oshteteni-so-neraspredelbata-naparite/] Accessed 02.03.2019.

57 Commission Staff working document - The Former Yugoslav Republic of Macedonia Report 2018, European Commission, Brussels, SWD [2018]

58 Petreski, B., Sustainability of the pension system in Macedonia Comprehensive analysis and reform proposal with MK-PENS -Dynamic Microsimulation Model, FinanceThink - Economic Research and Policy In- 
pension consisted of two parts: the contribution from the gross salary of the pension member and the benefit earned by capitalization (accumulation) of the asset / units.

Key problem is the accumulation of financial assets, through the mechanism of appropriation funds, from the gross salary of employed persons and bring in those assets into the pension and disability insurance fund as well as from the current budget of the state, in order to provide a regular payment of pensions to the beneficiaries and to distribute evenly the burden of provision funds (trying to provide as much as possible participation of the fund's assets instead of assets from the central budget).

Reform processes were expected to stabilize the Macedonian pension system, without raising the age limit for exercising the right to pension and provide equality between the present and future pensioners. At the same time, deficit of assets in the Pension and disability insurance funds would be on the decrease, budget funds transferred to the pensions would be reduced and eventual problems and difficulties in the payment of future pensions would be eliminated.

The expected benefits from the second pillar were: transferring part of the financial burden to the insurers; reducing the older people care expenses for the next generations; stabilized income of pensioners that will not be dependent on the demographic factors; increase in the individuals' work initiatives and social insurance to provide for their future; income will not be depended only on paid contributions in the previous years, but also on the income from interest rates, dividends and other investments. ${ }^{59}$

Instead, the pension reform caused additional budget expenditure for the Government and a financial challenge for the Public Fund.

The analyze of the reformed pension system through the prism of EU recommendations showed that our country has implemented the pension reforms as the most of the Middle East countries in Europe did. But, according to the last annual report of the European Commission on Republic of North Macedonia for 2018 the provision setting a $50 \%$ limit on investing in non-domestic securities by pension funds remains contrary to the acquis, ${ }^{60}$ despite the fact that the same remark is present in all the European Commission reports, starting from 2011 till

stitute, Skopje, available at [http://www.financethink.mk/wp-content/uploads/2018/06/Pension-analysis-EN.pdf] Accessed 02.03.2019

59 Bornarova, et al., op. cit. note 49, p. 396

60 Commission Staff working document - The Former Yugoslav Republic of Macedonia Report 2018, European Commission, Brussels, SWD [2018] 
now. These reports contained another remark regarding the withdrawals (transfers) from the Public to the Private funds, which were made with delay. Delayed transfer of funds from the state pension insurance fund to private funds resulted in a breach of the legislation on the management of deposits till $2017 .{ }^{61}$

Today, according to the latest EU progress report on North Macedonia, this problem has been overcome.

\section{REFERENCES}

\section{BOOKS AND ARTICLES}

1. Bornarova, S.; Bogoevska, N.; Trojevik, S., Pension System Reforms in the Republic of Macedonia: Expected Benefits and Challenges u: Academic Journal of Interdisciplinary Studies MCSER Publishing - Rome, Italy, vol. 2 No. 9, 2013, pp. 393-399

2. Kruse, A., A Stable Pension System: The Eighth Wonder, in: Bengtsson, T. (ed.), Population Ageing - A Threat to the Welfare State? Research in Labor Economics 22, 2010, p. $369-413$

3. Mustafai, H., Pension System Reform in the Republic of Macedonia, International Refereed Scientific Journal Vision, vol. 1, Issue 1, March 2017, pp. 69-78

4. Nikolov, M.; Shukarov, M.; Velkovska, I., Sustainability of the Republic of Macedonia pension fund, Economic analysis centre, Skopje, 2017, p. 8

5. Talevski, P., The Financing of the pension systems, Selektor, Skopje, 2009

6. Verbič, M.; Majcen, B.; Nieuwkoop, R, V. Sustainability of the Slovenian Pension System: An Analysis with an Overlapping-Generations General Equilibrium Model, Institute for Economic Research, Ljubljana, Slovenia, 2014, p. 62

\section{EU DOCUMENTS}

1. Carone G., Eckefeldt P., Giamboni L., Laine V., and Pamies S., Pension reforms in the EU since the early 2000's: achievements and challenges ahead, European Commission, Directorate Generale for Economic and Financial Affairs-DG ECFIN 20 December 2016, Available at [https://mpra.ub.uni-muenchen.de/78163/ MPRA Paper No. 78163, posted 8 April 2017] Accessed 14.04.2019

2. Commission Staff Working Document - The Former Yugoslav Republic of Macedonia Report 2015, European Commission, Brussels, SWD [2015]

3. Commission Staff working document - The Former Yugoslav Republic of Macedonia Report 2016, European Commission, Brussels, SWD [2016]

4. Commission Staff working document - The Former Yugoslav Republic of Macedonia Report 2018, European Commission, Brussels, SWD [2018]

5. Directive on the activities and supervision of institutions for occupational retirement provision 2003/41/EC

${ }_{61}$ Commission Staff working document - The Former Yugoslav Republic of Macedonia Report 2018, European Commission, Brussels, SWD [2018] 
6. Eatock, D., European Union pension systems Adequate and Sustainable?, Briefing November 2015, European Parliamentary Research System, available at [http://www.europarl.europa.eu/RegData/etudes/BRIE/2015/571327/EPRS_BRI(2015)571327_EN.pdf] Accesed 02.03.2019

7. European Commission - Commission Staff working paper: The FYROM 2011 Progress Report, Brussels, [2011], available at [https://ec.europa.eu/neighbourhood-enlargement/ sites/near/files/pdf/key_documents/2011/package/mk_rapport_2011_en.pdf] Accessed 04.03.2019

8. European Commission - Commission Staff working paper: The FYROM 2012 Progress Report, Brussels, [2012, available at [https://ec.europa.eu/neighbourhood-enlargement/ sites/near/files/pdf/key_documents/2012/package/mk_rapport_2012_en.pdf] Accessed 04.03.2019

9. European Commission - Green Paper towards adequate, sustainable and safe European pension systems SEC(210)830, Brussels [2010]

10. European Commission - White Paper An agenda for Adequate, Safe and Sustainable Pensions , Brussels [2012]

11. European Commission Directorate - General for Employment, Social Affairs and Inclusion, Social Protection Committee, The 2018 Pension Adequacy Report: current and future income adequacy in old age in the EU, Volume 1, 2018 Luxembourg

12. European Commission: Europe 2020, A European strategy for smart, sustainable and inclusive growth, Brussels, 3.3.2010, Available at [http://ec.europa.eu/eu2020/pdf/COMPLET\%20EN\%20BARROSO\%20\%20\%20007\%20-\%20Europe\%202020\%20-\%20 EN\%20version.pdf] Accessed 12.04.2019

13. Lanno, K.; Barslund, M.; Chmelar, A.; von Werder, M., Pension Shemes - Study for the EMPL Committee, 2014, prepared on request by the European Parlament's Committee on Employment and Social Affairs.

\section{LIST OF NATIONAL REGULATIONS}

1. Decision of the Constitutional Court of Republic of North Macedonia No. 114/2014-0-1 from 29.06.2016

2. Law on transforming enterprises with Social Capital, Official Gazette no. 38/1993

3. Law on Labor Relations, Official Gazette of the Republic of Macedonia No.62/2005; $106 / 2008$; 161/2008; 114/2009; 130/2009; 149/2009; 50/2010; 52/2010; 124/2010; $47 / 2011 ; 11 / 2012 ; 39 / 2012 ; 13 / 2013 ; 25 / 2013 ; 170 / 2013 ; 187 / 2013,113 / 2014,20 / 2015$, $33 / 2015,72 / 2015,129 / 2015,27 / 2016$ and 120/2018)

4. Law on Mandatory Fully Funded Pension Insurance, Official Gazette No. 29/2002, 85/2003, 40/2004, 113/2005, 29/2007, 88/2008, 48/2009, 50/2010, 171/2010, 36/2011, $98 / 2012,13 / 2013,164 / 2013,44 / 2014,192 / 2015,30 / 2016$ and $21 / 2018$

5. Law on Payment of Pensions and Pension Benefits from Fully Funded Pension Insurance, Official Gazette No. 11/2012, 147/2015 and 30/2016

6. Law on pension and disability Insurance from 1993, Official Gazette 24/2000 
7. Law on Pension and Disability Insurance, Official Gazette No. 98/2012, 166/12, 15/13, 170/13, 43/14, 44/14, 97/14, 113/14, 160/14, 188/14, 20/15, 61/15, 97/15, 129/15, $147 / 15,154 / 15,173 / 15,217 / 15,27 / 16,120 / 16,132 / 16$ and $35 / 2018$

8. Law on Voluntary Fully Funded Pension Insurance, Official Gazette No. 7/2008, 124/2010, $17 / 2011$ and $13 / 2013$

\section{WEBSITES AND OTHER}

1. Gerovska, M., M., ESPN Thematic Report: Assessment of Pension Adequacy in the former Yugoslav Republic of Macedonia, 2017, document prepared for the European Commission

2. [http://www.edac.eu/policies_desc.cfm?v_id=66]

3. [http://www.edac.eu/policies_desc.cfm?v_id=66]

4. [https://ec.europa.eu/social/main.jsp?catId=752]

5. [https://ec.europa.eu/social/main.jsp?catId=752]

6. [https://portalb.mk/499612-analize-pensionistet-do-ta-tejkalojne-numrin-333-000-afer1-miliarde-euro-per-pagesen-e-tyre/..]

7. [https://www.finance.gov.mk/mk/node/7703]

8. [https://www.ilo.org/wcmsp5/groups/public/---dgreports/---]

9. [dcomm/documents/publication/wcms_310211.pdf]

10. MAPAS Report On the Developments in the Fully Funded Pension Insurance in 2013, Skopje, 2014.

11. Ministry of Finance of the Republic of Macedonia, Draft Budget of the Republic of Macedonia for 2019. [https://www.finance.gov.mk/files/u3/Prelog\%20budzet\%202019\%2004.pdf]

12. Ministry of labor and social policy of the Republic of Macedonia, How to get a fair and stable pension system. [http://mtsp.gov.mk/content/pdf/dokumenti/2018/MTSP\%20 prezentacija\%2002.pdf]

13. Petreski B., Sustainability of the pension system in Macedonia Comprehensive analysis and reform proposal with MK-PENS - Dynamic Microsimulation Model, FinanceThink - Economic Research and Policy Institute, Skopje, available at [http://www.financethink.mk/wp-content/uploads/2018/06/Pension-analysis-EN.pdf] Accessed 02.03.2019

14. Šonje, V.(2011) Pension systems and pension reforms: Case of Croatia (with a review of reforms in 13 emerging European countries), October 2011, available at [http://arhivanalitika.hr/wp/ wp-content/uploads/2017/02/PENSION-SYSTEMS-AND-PENSION-REFORM_final. pdf] Accessed 10.04.2019 